\title{
Efektivitas intervensi teen anger management and education dalam mengatasi kemarahan dan agresivitas remaja perempuan
}

\author{
Claudya Carolina ${ }^{1}$ dan Mita Aswanti Tjakrawiralaksana ${ }^{2}$
}

\begin{abstract}
Anger management based on the cognitive-behavioral approach is considered an effective intervention to treat anger and aggressivity in adolescence. This study investigates the effectiveness of the cognitive-behavioral intervention on anger in female middle-high school students in Depok. Eight female adolescents (age 12-14) were recruited to participate in this intervention using the purposive sampling method. Anger level was measured during the pretest, post-test, and follow-up phases using a self-report questionnaire and a program evaluation sheet. WilcoxonSign Rank test showed no significant difference in the participants' anger level between the three measurement phases. However, according to the program evaluation, the result shows that the participants applied new strategies to deal with their anger and aggressive behavior. Statistically, the cognitive-behavioral intervention was not effective for treating anger in female adolescents. However, participants were reported to use more adaptive strategies in managing their anger. This intervention could be applied for overcoming aggression and anger in female adolescents in the future.
\end{abstract}

\section{Keywords}

anger management, aggressive behavior, adolescent, cognitive-behavioral approach, intervention

\section{Pendahuluan}

Kasus agresivitas yang dilakukan oleh remaja perempuan terlihat cukup marak selama beberapa tahun terakhir. Berdasarkan Survei Nasional Pengalaman Hidup Anak dan Remaja (SNPHAR) pada tahun 2018, terlihat bahwa remaja perempuan lebih banyak melakukan kekerasan fisik kepada teman sebayanya dalam kurun waktu 12 bulan terakhir dibandingkan remaja laki-laki (Kementerian Pemberdayaan Perempuan dan Perlindungan Anak, 2020). Di dalam dua tahun ke belakang, terdapat beberapa kasus agresivitas remaja perempuan yang informasinya menyebar luas di Indonesia, misalnya kasus pengeroyokan seorang remaja perempuan di Pontianak yang terjadi pada tahun 2019 (Fadhli, 2019) dan kasus perundungan yang dilakukan oleh sekelompok remaja perempuan terhadap rekannya di Solo pada tahun 2020 (Zamani, 2020).

Jika dilihat secara definisi, agresivitas merupakan segala bentuk tindakan yang bertujuan untuk membahayakan atau melukai seseorang (Krahé, 2013). Terjadinya agresivitas pada remaja perlu mendapatkan penanganan serius karena masalah tersebut dapat menjadi sumber kesulitan mereka untuk menyesuaikan diri dengan tuntutan lingkungan (Feindler \& Engel, 2011). Terjadinya perilaku agresif pada remaja dapat disebabkan oleh beberapa hal, misalnya adanya tekanan dalam hal pertemanan peer pressure (Liu et al., 2013) serta kesulitan remaja dalam meregulasi emosi negatifnya (Herts et al., 2012) Perilaku agresif yang dilakukan oleh remaja merupakan salah satu penyebab dikeluarkannya remaja dari sekolah (Kokko et al., 2006; Oh et al., 2018). Jika tidak tertangani, masalah agresivitas tersebut dapat bertahan sepanjang waktu dan dapat membuat remaja tersebut terlibat dalam perilaku kriminal di masa dewasa (Pingault et al., 2013).

Masalah agresivitas berkaitan erat dengan adanya kesulitan seseorang dalam meregulasi kemarahannya (Sullivan et al., 2017). Di Indonesia, tercatat sejumlah kasus agresivitas pada remaja perempuan yang dipicu oleh adanya kemarahan, misalnya kasus pembunuhan yang dilakukan oleh remaja perempuan di Tegal terhadap temannya sendiri (Budi, 2019). Kejadian bermula saat pelaku merasa tersinggung oleh kata-kata kasar yang dilontarkan korban sehingga pelaku secara tega menganiaya korban hingga meninggal dunia. Pada kasus tersebut, terlihat bahwa kemarahan yang dirasakan oleh pelaku mendorong terjadinya tindakan agresif yang memiliki dampak serius.

\footnotetext{
${ }^{1,2}$ Fakultas Psikologi Universitas Indonesia

Korespondensi:

Claudya Carolina, Fakultas Psikologi Universitas Indonesia, Kampus Baru UI - Depok

Email: claudya.carolina@gmail.com
} 
Oleh sebab itu, kemarahan perlu dipertimbangkan dalam pembahasan kasus-kasus terkait agresivitas.

Secara definisi, kemarahan atau emosi marah (anger) diartikan sebagai suatu emosi negatif yang melibatkan faktor kognitif, memunculkan rangsangan fisiologis, serta meningkatkan intensi untuk melukai orang lain (Berkowitz, 2012). Kemarahan biasanya muncul akibat adanya rasa frustrasi atau terjadinya provokasi dalam suatu interaksi sosial (Sukhodolsky et al., 2016). Pada suatu studi longitudinal, ditemukan bahwa kemarahan berperan secara konsisten dalam memprediksi masalah agresivitas pada remaja (Neumann et al., 2011). Meskipun bukan satu-satunya faktor pencetus tindakan agresif (Berkowitz, 2012), peran kemarahan cukup banyak terlihat pada sejumlah kasus yang berkaitan dengan agresivitas (Lochman et al., 2010).

Kaitan antara terjadinya perilaku agresif dan kemarahan dapat dijelaskan melalui pendekatan kognitif perilaku. Ketika terjadi suatu peristiwa yang mengarah pada provokasi, sejumlah proses kognitif seperti atribusi, ekspektasi, serta kemampuan pemecahan masalah berperan terhadap bagaimana seseorang menginterpretasikan suatu peristiwa. Keberadaan kepercayaan irasional dan distorsi kognitif dapat membuat seseorang keliru dalam menginterpretasikan suatu peristiwa sehingga seseorang dapat melakukan suatu tindakan agresif (Fives et al., 2011). Kemudian, kemarahan yang intens serta kurang teregulasi dapat memperkuat terjadinya suatu distorsi kognitif yang dimiliki seseorang sehingga hal tersebut dapat mempercepat terjadinya respon yang impulsif dan agresif pada kejadian provokatif (Feindler \& Engel, 2011). Adanya keterkaitan yang erat antara perilaku agresif dan kemarahan menyebabkan sejumlah intervensi untuk mengatasi masalah agresivitas menyasar pada aspek emosi marah (kemarahan) yang dimiliki individu.

Berbagai jenis intervensi telah dikembangkan guna mengatasi masalah kemarahan pada remaja, di antaranya yaitu pendidikan afeksi, pelatihan teknik relaksasi, restrukturisasi kognitif, teknik pemecahan masalah, hingga pelatihan keterampilan sosial (Blake \& Hamrin, 2007). Dari berbagai intervensi yang ada, teknik manajemen marah (anger management) yang berfokus pada aspek kognitif dan perilaku (cognitive-behavioral therapy) ditemukan cukup efektif dalam menurunkan tingkat kemarahan serta agresivitas pada remaja (Candelaria t al., 2012). Pada intervensi marah yang berfokus pada kognitif perilaku, klien akan dibantu untuk meregulasi kemarahan mereka yang intens dan mengubah distorsi kognitif yang menyebabkan terjadinya peristiwa marah (Feindler \& Engel, 2011). Adanya perubahan dalam hal kognitif tersebut diharapkan dapat membantu remaja menyadari kemarahan yang mereka rasakan. Di samping aspek kognitif, pada intervensi kognitif-perilaku, remaja juga akan diajarkan teknik yang dapat digunakan untuk menurunkan emosi negatif yang mereka rasakan serta teknik pemecahan masalah yang dapat mereka gunakan di kehidupan sehari-hari. Dengan demikian, diharapkan masalah agresivitas mereka miliki dapat menurun seiring dengan meningkatnya kemampuan mereka dalam meregulasi kemarahannya.

Meskipun intervensi manajemen marah dianggap dapat mengatasi masalah terkait kemarahan dan agresivitas, kebanyakan intervensi manajemen marah dianggap memiliki kecenderungan bias gender karena lebih berfokus pada masalah yang terdapat pada remaja laki-laki dibandingkan remaja perempuan (Collins, 2014). Hal itu tampaknya terjadi karena adanya temuan bahwa prevalensi remaja laki-laki yang terlibat dalam masalah kekerasan dan kenakalan remaja cenderung lebih tinggi dibandingkan remaja perempuan (Baxendale et al., 2012). Di samping itu, adanya kecenderungan bahwa laki-laki biasa menampilkan kemarahannya ke luar dibandingkan perempuan yang lebih sering menyembunyikan kemarahan sendiri tampaknya membuat masalah kemarahan pada perempuan kurang mendapatkan perhatian (Chaplin \& Aldao, 2013).

Di Indonesia sendiri, sudah terdapat penelitian sebelumnya yang berfokus pada pemberian intervensi manajemen marah pada kelompok remaja laki-laki (Nasrizulhaidi et al., 2015), tetapi sejauh pengetahuan peneliti, belum ada penelitian terkait manajemen marah yang secara spesifik berfokus pada kelompok remaja perempuan. Padahal, masalah terkait kemarahan dan agresivitas pada perempuan juga ditemukan memiliki dampak yang buruk. Sebagai contoh, pada penelitian yang dilakukan (Preddy et al., 2012), ditemukan bahwa agresivitas pada perempuan berhubungan dengan terjadinya masalah penyesuaian diri perempuan di lingkungan sosial, misalnya menjadi tidak disukai kelompoknya dan kesepian. Di samping itu, masalah terkait kemarahan dan agresivitas pada remaja perempuan juga ditemukan berhubungan dengan perilaku kriminal seperti halnya remaja laki-laki (Hornsveld et al., 2018). Oleh sebab itu, intervensi manajemen marah bagi remaja perempuan juga diperlukan agar remaja perempuan memiliki kemampuan dalam mengelola kemarahan serta mengontrol perilaku agresif yang mereka lakukan.

Beberapa penelitian menemukan bahwa pemberian intervensi manajemen marah memberikan dampak yang signifikan terhadap penurunan kemarahan dan agresivitas pada remaja perempuan (Jahanian \& Alizadeh, 2018; Mokhber et al., 2016; Pepler et al., 2010). Akan tetapi, terdapat pula penelitian yang belum berhasil menunjukkan hasil yang tidak signifikan dari intervensi manajemen marah terhadap masalah pada remaja perempuan (Erickson, 2013; Goldstein et al., 2007). Meskipun hasil penelitian tergolong inkonsisten, intervensi manajemen marah pada remaja perempuan tampaknya cukup dibutuhkan bagi kelompok tersebut. Pada studi pendahuluan yang dilakukan Burt (2014) ditemukan bahwa remaja perempuan tampak memberikan respon dan penerimaan yang lebih baik dibandingkan remaja laki-laki saat mendapatkan intervensi. Adanya penerimaan yang lebih baik pada remaja perempuan diduga terjadi karena remaja perempuan cenderung lebih jarang mendapatkan penanganan 
untuk masalah perilaku mereka dibandingkan remaja lakilaki (Burt, 2014). Pada studi tersebut, ditemukan bahwa remaja perempuan yang menjadi partisipan penelitian sebenarnya ingin mendapatkan layanan untuk mengatasi masalah mereka apabila layanan tersebut tersedia. Akan tetapi, remaja perempuan tersebut merasa belum mendapatkan layanan seperti yang biasanya diberikan kepada remaja laki-laki. Hal ini mengindikasikan bahwa pemberian intervensi semacam manajemen marah dibutuhkan oleh remaja perempuan agar mereka dapat terbantu untuk menyelesaikan masalah yang mereka miliki.

Salah satu intervensi marah yang dapat diaplikasikan untuk remaja perempuan adalah Teen Anger Management Education/TAME (Feindler \& Gerber, 2008). Intervensi TAME dibuat untuk mengatasi masalah pengelolaan emosi marah dan perilaku agresif pada remaja dengan menyasar pada aspek kognitif dan perilaku. Pada intervensi TAME, remaja akan diajarkan untuk mengenali dan meregulasi kemarahan, serta mencegah kemunculan perilaku agresif dengan menerapkan teknik pemecahan masalah saat terdapat provokasi di lingkungan (Feindler \& Engel, 2011; Feindler \& Gerber, 2008). Dalam hal ini, remaja akan diajarkan beberapa teknik untuk meredakan kemarahannya. Setelah mempelajari teknik manajemen marah tersebut, diharapkan remaja dapat memahami kondisi yang dialaminya saat marah serta dapat menentukan respon yang tepat berdasarkan pemecahan masalah yang dilakukan. Dengan demikian, kemunculan perilaku agresif yang terjadi pada remaja diharapkan dapat berkurang.

Intervensi manajemen marah menggunakan TAME dapat digunakan di berbagai setting serta beragam populasi, mulai dari remaja di setting sekolah hingga remaja dengan masalah perilaku klinis yang berada institusi sosial (Feindler \& Engel, 2011). Protokol pelaksanaan intervensi ini tergolong mudah diadministrasikan karena dapat disesuaikan dengan kebutuhan. Secara umum, terdapat tiga komponen utama pada intervensi TAME, yaitu regulasi emosi, restrukturisasi kognitif, dan resolusi konflik (Feindler \& Gerber, 2008). Program intervensi ini akan ditampilkan dalam metode pengajaran, pemberian contoh, pengulangan yang dilakukan melalui aktivitas bermain peran, serta pengaplikasian materi yang diberikan dalam situasi sehari-hari melalui pemberian tugas harian yang harus dikerjakan oleh remaja. Adanya pemberian tugas diharapkan dapat membantu remaja untuk menyadari kondisi yang mereka alami saat marah serta belajar untuk mempraktikkan teknik yang diajarkan selama intervensi pada lingkungan yang sebenarnya. Tugas yang diberikan akan dibahas pada sesi berikutnya agar remaja mendapatkan umpan balik dari tindakan yang mereka lakukan pada saat menghadapi situasi yang memicu kemarahan tersebut.

Intervensi manajemen marah menggunakan TAME dapat dilakukan secara individual maupun berkelompok. Meskipun begitu, intervensi yang diberikan pada remaja umumnya dilakukan dalam format berkelompok (Down et al., 2011). Intervensi yang dilakukan secara berkelompok dianggap lebih ekonomis dan efisien (Hoogsteder et al., 2015). Adanya anggota kelompok memungkinkan setiap individu yang menjadi partisipan intervensi untuk melakukan role-playing serta modeling teknik pengelolaan kemarahan di beragam situasi (Blake \& Hamrin, 2007). Di samping itu, adanya teman-teman di dalam kelompok dapat membuat situasi dalam aktivitas bermain peran menjadi lebih alami layaknya situasi sehari-hari yang dihadapi partisipan (Feindler \& Engel, 2011).

Seperti yang telah disebutkan sebelumnya, intervensi TAME merupakan salah satu intervensi yang dapat diadministrasikan kepada remaja perempuan maupun remaja laki-laki, baik di dalam grup yang terdiri dari sekelompok remaja dengan gender yang sama ataupun berbeda. Meskipun demikian, Feindler \& Gerber (2008) menyarankan agar pelaksanaan intervensi TAME dilakukan dalam grup yang terdiri dari gender yang sama. Artinya, intervensi TAME sebaiknya dilakukan dengan memisahkan antara kelompok yang terdiri dari remaja perempuan atau remaja laki-laki saja. Pemisahan tersebut baiknya dilakukan agar remaja tidak terdistraksi oleh keberadaan anggota dari gender yang berbeda (Feindler \& Gerber, 2008). Adanya penggabungan antara partisipan laki-laki dan perempuan di dalam intervensi pada remaja dapat membuat terjadinya kecanggungan sehingga partisipan menjadi defensif (Down et al., 2011). Pada intervensi TAME, terdapat sejumlah kegiatan bermain peran yang dapat membuat remaja akan merasa sungkan ketika berada di satu kelompok yang sama dengan gender yang berbeda. Di samping itu, adanya masalah serta pengekspresian kemarahan yang berbeda antara remaja perempuan dan laki-laki membuat intervensi ini akan lebih baik dilakukan di dalam kelompok dengan gender yang sama. Pada penelitian ini, peneliti ingin melihat efektivitas pemberian intervensi manajemen marah menggunakan TAME kepada sekelompok remaja perempuan tingkat sekolah menengah pertama SMP yang dikeluhkan memiliki masalah agresivitas dan kemarahan. Remaja perempuan dipilih sebagai partisipan intervensi karena kelompok tersebut cenderung lebih jarang mendapatkan intervensi dibandingkan kelompok remaja laki-laki. Peneliti menduga bahwa intervensi yang diberikan kelompok remaja perempuan dapat memberikan perubahan yang signifikan bagi penurunan agresivitas dan kemarahan mereka. Dengan adanya penanganan awal, diharapkan masalah agresivitas dan kemarahan remaja perempuan tersebut tidak berkembang menjadi suatu hal yang serius di kemudian hari.

Di samping itu, penelitian ini juga diharapkan dapat menambah literatur mengenai efektivitas intervensi manajemen marah berbasis kelompok dalam menangani masalah agresivitas dan kemarahan pada remaja perempuan di Indonesia. Terlebih, penelitian terhadap populasi tersebut tergolong lebih jarang dilakukan dibandingkan pada kelompok remaja laki-laki. Peneliti menduga bahwa pemberian intervensi manajemen marah pada 
remaja perempuan juga dapat memberikan perubahan positif berupa penurunan tingkat kemarahan dan agresivitas mereka. Peneliti berharap bahwa hasil penelitian ini dapat memberikan manfaat bagi remaja perempuan yang cenderung lebih jarang mendapatkan intervensi terkait kemarahan dan agresivitas.

\section{Metode}

\section{Desain Penelitian}

Penelitian ini menggunakan within-subjects experimental design karena hanya terdapat satu (1) kelompok yang terlibat di dalam intervensi. Pada desain penelitian ini, peneliti akan membandingkan partisipan pada fase berbeda. Terdapat tiga fase yang dibandingkan, yaitu pada fase pre-test (sebelum diberikan intervensi), post-test (setelah dilakukan intervensi), serta pada fase follow-up (satu bulan setelah intervensi selesai diberikan).

\section{Subjek}

Partisipan penelitian ini adalah 8 remaja perempuan dengan masalah terkait kemarahan dan agresivitas di salah satu SMP di kota Depok. Kedelapan partisipan tersebut memiliki rentang usia antara 12 hingga 14 tahun dan memiliki kemampuan intelektual yang tergolong taraf rata-rata (berdasarkan tes Standard Progressive Matrices; $S P M)$. Seluruh partisipan memiliki skor kemarahan yang tergolong tinggi (skor tes Buss-Perry Aggression Questionnaire - Anger Subscale/BPAQ-AS lebih tinggi atau sama dengan 17). Di samping itu, penilaian kemarahan dan agresivitas pada partisipan dilakukan melalui wawancara guru. Berdasarkan penilaian guru, sejumlah remaja perempuan yang menjadi siswi di SMP ini kerap menampilkan perilaku agresif seperti mengumpat teman, melakukan pemaksaan, serta membantah apa yang dikatakan guru. Meskipun guru telah memberikan peringatan secara lisan, hal tersebut tampak kurang efektif karena mereka masih kerap mengulangi perbuatannya di kemudian hari.

\section{Instrumen Penelitian}

\section{Instrumen Screening}

Terdapat dua instrumen screening yang digunakan yaitu 1) Lembar data partisipan, digunakan untuk mendapatkan gambaran identitas partisipan yang mengungkap identitas partisipan, identitas orang tua, dan keterangan saudara. 2) Standard Progressive Matrices (SPM) merupakan alat ukur penalaran umum nonverbal untuk menyaring siswa-siswa yang memiliki kapasitas cukup dalam menerima materi yang diberikan di dalam intervensi.

\section{Instrumen Evaluasi}

Buss-Perry Aggression Questionaire - Anger Subscale. Peneliti menggunakan alat ukur alat ukur BussPerry Aggression Questionaire - Anger Subscale (BPAQ$A S$ ) pada dimensi anger (Buss \& Perry, 1992) untuk mengukur tingkat kemarahan siswa. Alat ukur $B P A Q-A S$ terdiri dari 7 item. Terdapat lima pilihan skala likert dalam alat ukur tersebut, yaitu dari 1 (sangat tidak sesuai dengan diri saya) hingga 5 (sangat sesuai dengan diri saya). Item pada nomor 4 pada alat ukur ini perlu diskor secara terbalik (reversed). Skoring dilakukan dengan cara menjumlahkan ketujuh item dalam kuesioner dengan sebelumnya menerjemahkan terbalik item nomor 4 terlebih dahulu. Berdasarkan penelitian Gestantya (2014), siswa dikatakan memiliki tingkat kemarahan yang tinggi apabila ia mendapatkan skor lebih tinggi atau sama dengan 17. Oleh sebab itu, pada intervensi ini, peneliti akan memlih siswa-siswa yang memiliki skor lebih tinggi atau sama dengan 17 untuk menjadi partisipan.

Lembar Kerja. Lembar kerja diberikan saat intervensi berlangsung. Pada lembar tersebut, partisipan diminta untuk mengerjakan tugas yang diberikan oleh peneliti. Tugas tersebut diberikan secara individual maupun berkelompok sesuai materi yang diberikan.

Lembar Refleksi dan Evaluasi. Lembar refleksi dan evaluasi merupakan lembar yang perlu diisi oleh partisipan saat fase post-test dan follow-up. Pengisian lembarlembar tersebut bertujuan untuk mengetahui gambaran pengetahuan yang diperoleh partisipan setelah mendapatkan intervensi. Di samping itu, lembar tersebut juga bertujuan untuk melihat gambaran kondisi yang dirasakan oleh partisipan setelah mengikuti intervensi.

\section{Prosedur Intervensi}

Intervensi manajemen marah bagi remaja perempuan ini dilaksanakan pada periode bulan September hingga November 2019 di salah satu sekolah menengah pertama (SMP) swasta di kota Depok. Intervensi terbagi menjadi empat kegiatan utama, yaitu pengukuran sebelum intervensi (pre-test), pelaksanaan intervensi, pengukuran setelah intervensi (post-test), dan pengukuran tindak lanjut setelah tidak dilakukannya intervensi (follow-up). Peneliti melakukan pre-test untuk menyaring remaja perempuan dengan tingkat kemarahan yang tinggi dan dengan kemampuan kognitif yang tergolong rata-rata. Setelah mendapatkan skor kemarahan, peneliti berkonsultasi dengan guru sekolah untuk memeroleh data kualitatif terkait masalah marah dari calon partisipan sebelum memilih partisipan yang sesuai untuk diikutsertakan di dalam intervensi. Peneliti selanjutnya meminta kesediaan partisipan untuk mengikuti intervensi dengan menandatangani lembar informed consent sebelum sesi intervensi dilaksanakan. Setelah intervensi berakhir, peneliti melakukan post-test (setelah sesi intervensi terakhir berakhir) dan follow-up (1 bulan setelah intervensi berakhir) guna mengetahui tingkat kemarahan yang dirasakan oleh seluruh partisipan setelah mendapatkan intervensi manajemen marah.

Intervensi Teen Anger Management and Education (TAME) diberikan secara berkelompok dengan dipandu oleh satu orang fasilitator utama (peneliti) dan dua orang asisten fasilitator. Adanya dua asisten fasilitator dapat 
membantu tugas fasilitator utama dalam memantau setiap partisipan di dalam kelompok intervensi. Fasilitator utama dan asisten fasilitator merupakan mahasiswa semester 5 dari program Magister Profesi Psikologi Klinis Anak di Fakultas Psikologi Universitas Indonesia. Terdapat 6 sesi intervensi $T A M E$ yang diberikan kepada partisipan. Secara umum, intervensi ini terdiri dari 6 sesi. Pada sesi pertama intervensi, partisipan mendapatkan materi psikoedukasi mengenai pengenalan emosi, terutama emosi marah serta teknik relaksasi. Pada sesi kedua, partisipan diberikan pengajaran mengenai metode yang dapat digunakan untuk mengidentifikasi pemicu, reaksi, dan konsekuensi dari rasa marah. Pada sesi ketiga, partisipan diberikan psikoedukasi tentang teknik menyanggah keyakinan yang bersifat agresif.

Selanjutnya pada sesi keempat, partisipan diajarkan teknik pengendalian diri yang dilakukan dengan mengingatkan diri sendiri. Pada sesi kelima, partisipan diberikan psikoedukasi dan latihan tentang teknik bepikir jangka panjang. Terakhir, pada sesi keenam, partisipan diajarkan untuk membuat rencana tindakan yang akan dilakukan jika dihadapkan pada situasi yang dapat memicu kemarahan. Pada pelaksanaannya, terdapat penambahan 1 sesi intervensi sehingga total sesi yang diberikan adalah 7 sesi. Seluruh rangkaian penelitian ini telah memenuhi standar etis dari Komite Etika Penelitian Fakultas Psikologi Universitas Indonesia. Deskripsi mengenai intervensi dapat dilihat pada Tabel 1:

\section{Analisis Data}

Peneliti melakukan melakukan analisis data menggunakan teknik statistik non-parametrik berupa Wilcoxon-Signed Rank test. Teknik statistik tersebut memungkinkan peneliti untuk melihat perbedaan skor kemarahan (skor BPAQ-AS) partisipan pada fase pre-test dan post-test, pre-test dan follow-up, serta post-test dan followup. Selain analisis kuantitatif, peneliti juga melakukan analisis kualitatif terhadap perubahan yang dirasakan oleh partisipan intervensi dari sebelum dan sesudah intervensi, serta satu bulan setelah intervensi. Analisis kualitatif ini dilakukan dengan metode analisis tema (thematic analysis), yaitu metode kualitatif yang meliputi pencarian tema guna mengidentifikasi pola pada suatu data Willig (2013). Berdasarkan metode tersebut, peneliti melakukan pengelompokan tema yang muncul pada jawaban partisipan setelah mengisi lembar refleksi dan berdasarkan hasil diskusi yang dipandu oleh peneliti. Dalam hal ini, peneliti melihat tema dari respon yang muncul pada partisipan terkait perubahan kemarahan yang mereka rasakan, pengalaman mereka dalam menghadapi situasi marah atau melakukan tindakan agresif sebelum dan setelah mendapatkan intervensi, serta bagaimana mereka menerapkan hal-hal yang telah diberikan selama intervensi di dalam kehidupan sehari-hari.

\section{Hasil}

\section{Hasil dan Analisis Kuantitatif}

Berdasarkan Tabel 2, terlihat bahwa empat dari delapan partisipan mengalami penurunan skor kemarahan $(B P A Q-$ $A S)$ dari fase pre-test ke post-test. Di sisi lain, dua partisipan tampak memiliki skor kemarahan yang sama pada fase pre-test ke post-test dan dua partisipan lainnya justru mengalami peningkatan skor kemarahan. Meskipun sebagian partisipan mengalami penurunan skor pada fase pre-test menuju post-test, terlihat bahwa lima partisipan justru mengalami peningkatan skor kemarahan dari fase post-test hingga follow-up, sedangkan tiga partisipan lainnya mengalami penurunan skor di antara kedua fase tersebut. Sementara itu, berdasarkan skor ratarata, terlihat adanya penurunan rata-rata skor kemarahan partisipan pada pengukuran pre-test $(M=25)$ ke posttest $(M=22)$, pre-test $(M=25)$ ke follow-up $(M=21.75)$, serta post-test $(M=22)$ ke follow-up $(M=21.75)$. Artinya, terjadi penurunan skor kemarahan partisipan pada ketiga fase tersebut. Meskipun begitu, diperlukan pengujian statistik lanjutan untuk mengetahui apakah terdapat penurunan skor kemarahan yang signifikan pada ketiga fase tersebut. Untuk itu, peneliti melakukan analisis statistik menggunakan Wilcoxon-Signed Rank test. Hasil penghitungan tersebut dapat dilihat pada Tabel 3.

Hasil perhitungan statistik deskriptif berdasarkan hasil pre-test ke post-test terdapat empat dari delapan partisipan (MR, IN, NZ, TH) mengalami penurunan skor kemarahan (BPAQ-AS) dan ada dua partisipan lainnya tampak tidak ada perbeadaan skor. Sedangkan dua partisipan lainnya (BL, SF) justru mengalami peningkatan skor kemarahan (ZH, SS).

Selanjutnya, berdasarkan skor rata-rata terlihat adanya penurunan rata-rata skor kemarahan partisipan pada pengukuran pre-test $(M=25)$ ke post-test $(M=22)$, pre-test $(M=25)$ ke follow-up $(M=21.75)$, serta post-test $(M=22)$ ke follow-up $(M=21.75)$. Artinya, terjadi penurunan skor kemarahan partisipan pada ketiga fase tersebut. Meskipun begitu, diperlukan pengujian statistik lanjutan untuk mengetahui apakah terdapat penurunan skor kemarahan yang signifikan pada ketiga fase tersebut (Tabel 2). Untuk itu, peneliti melakukan analisis statistik menggunakan Wilcoxon-Signed Rank test.

\section{Hasil dan Analisis Kualitatif}

Meskipun berdasarkan hasil penghitungan kuantitatif tidak ditemukan adanya penurunan tingkat kemarahan yang signifikan, terlihat adanya sejumlah perubahan kualitatif yang dirasakan oleh masing-masing partisipan intervensi. Gambaran terkait perubahan kualitatif tersebut dapat dilihat pada Tabel 4.

Pada kondisi sebelum intervensi, terlihat adanya suatu kesamaan tema jawaban partisipan berupa pengekspresian kemarahan dalam bentuk negatif. Dalam hal ini, 
Tabel 1. Deskripsi intervensi teen anger management and education (TAME)

\begin{tabular}{llr}
\hline Sesi & Tujuan & Durasi \\
\hline 1 & Meningkatkan pengetahuan dan kesadaran partisipan terhadap emosi marah dan agresivitas, serta & 90 menit \\
& pengajaran teknik relaksasi & \\
2 & Mengidentifikasi pemicu, reaksi, dan konsekuensi (antecedent - behavior - consequences) dari emosi marah & 60 menit \\
3 & Mengajarkan dan melatih teknik menyanggah keyakinan negatif/agresif & 45 menit \\
& $\begin{array}{l}\text { Tambahan: } \\
\text { Mendiskusikan masalah relasional yang sedang terjadi di antara partisipan serta mencari beragam solusi }\end{array}$ & 45 menit \\
& yang mungkin dilakukan untuk penyelesaian masalah & 90 menit \\
4 & Mengajarkan dan melatih teknik self - reminder & 90 menit \\
5 & Mengajarkan dan melatih teknik berpikir jangka panjang & 90 menit \\
6 & Mengajarkan teknik pemecahan masalah yang meliputi kegiatan melakukan evaluasi terhadap keseluruhan & \\
\hline
\end{tabular}

Tabel 2. Penghitungan statistik deskriptif skor marah partisipan (BPAQ-AS)

\begin{tabular}{lccc}
\hline & \multicolumn{3}{c}{ Fase } \\
\cline { 2 - 4 } Inisial Partisipan & Pre-test & Post-test & Follow-up \\
\hline ZH & 21 & 22 & 23 \\
BL & 22 & 22 & 23 \\
MR & 28 & 17 & 15 \\
IN & 24 & 21 & 25 \\
SF & 21 & 21 & 26 \\
SS & 29 & 31 & 21 \\
NZ & 30 & 19 & 22 \\
TH & 25 & 23 & 19 \\
\hline$M(s)$ & $25(3.63)$ & $22(4.11)$ & $21.75(3.5)$ \\
\hline
\end{tabular}

Tabel 3. Penghitungan statistik non-parametrik Wilcoxon-Signed Rank test

\begin{tabular}{lcc}
\hline Fase & $Z$ & $p$ \\
\hline Pre-test - Post-test & -1.48 & 0.140 \\
Pre-test - Follow-up & -1.13 & 0.261 \\
Post-test - Follow-up & -0.09 & 0.933 \\
\hline
\end{tabular}

seluruh partisipan cenderung mengekspresikan kemarahannya dalam secara negatif atau perilaku agresif, misalnya mengomeli orang lain, merusak barang, memukul, atau bersikap kasar kepada orang lain. Setelah mendapatkan intervensi, partisipan mendapatkan pengetahuan tentang teknik-teknik mengelola kemarahan. Tema jawaban yang muncul terkait respon kemarahan juga tampak lebih positif, misalnya beberapa partisipan merasa lebih bisa meredakan kemarahannya setelah mereka menerapkan teknik yang diajarkan (misalnya teknik "Tiga Napas" dan self-reminder). Selain itu, terdapat pula partisipan yang merasa lebih mampu berpikir lebih positif dalam melihat suatu peristiwa yang dapat pemicu kemarahan. Perubahan kualitatif yang dirasakan partisipan setelah intervensi mengindikasikan adanya manfaat yang dirasakan partisipan dari intervensi TAME yang diberikan. Meskipun demikian, hampir seluruh partisipan merasakan kendala dalam menerapkan teknik yang diajarkan di kehidupan sehari-hari. Dalam hal ini, mereka terkadang sudah terpicu marah terlebih dahulu sebelum menerapkan teknik yang diajarkan.

Pada fase pemantauan 1 bulan setelah intervensi (followup), terlihat bahwa seluruh partisipan masih merasakan adanya manfaat dari pemberian intervensi. Terlihat adanya tema bahwa beberapa partisipan masih dan menggunakan teknik mengelola marah yang diajarkan. Di samping itu, mereka juga masih menyadari pentingnya pengelolaan kemarahan bagi diri mereka dengan mengingat konsekuensi dari tindakan yang dilakukan di kemudian hari. Meskipun sudah menyadari hal tersebut, partisipan mengaku bahwa mengaplikasikan teknik pengelolaan marah di keseharian adalah hal yang cukup sulit dilakukan. Banyaknya pemicu marah serta kurangnya dukungan dari orang sekitar (justru diledek ketika menggunakan teknik mengelola marah yang diajarkan) tampak menyulitkan mereka untuk secara konsisten menerapkan teknik mengelola marah tersebut dalam lingkungan yang sebenarnya. Padahal, partisipan merasakan adanya manfaat dari penggunaan teknik mengelola marah yang diajarkan selama intervensi berlangsung.

\section{Pembahasan}

Intervensi Teen Anger Management and Education (TAME) yang diberikan ini bertujuan untuk mengetahui efektivitas pemberian manajemen marah dalam mengatasi kemarahan pada sekelompok remaja perempuan di salah satu SMP di Depok. Secara umum, terlihat adanya penurunan skor kemarahan pada empat partisipan di fase post-test dan tiga partisipan di fase follow-up. Selain itu, skor rata-rata tingkat kemarahan partisipan mengalami penurunan dari fase pre-test menuju posttest dan dari fase post-test menuju follow-up. Meskipun skor rata-rata partisipan mengalami penurunan, hasil penghitungan statistik menunjukkan bahwa tidak terdapat penurunan yang signifikan dari tingkat kemarahan dari sebelum hingga sesudah intervensi. Dengan kata lain, intervensi yang diberikan belum cukup efektif dalam menurunkan tingkat kemarahan pada remaja perempuan. Hasil tersebut sejalan dengan temuan dari beberapa penelitian sebelumnya yang tidak menemukan adanya efek yang signifikan dari pemberian intervensi manajemen 
Tabel 4. Perubahan kualitatif partisipan pada pre-test, post-test, hingga follow-up

\begin{tabular}{llll}
\hline Inisial & Fase Pre-test & Fase Post-test & Fase Follow-up \\
\hline ZH & $\begin{array}{l}\text { Mengekspresikan marah dengan } \\
\text { menggerutu dan bisa melampiaskan } \\
\text { kemarahannya secara lisan kepada }\end{array}$ & $\begin{array}{l}\text { Merasa lebih mampu mengendalikan } \\
\text { emosi dengan menggunakan teknik } \\
\text { "Tiga Napas" atau self-reminder. }\end{array}$ & $\begin{array}{l}\text { Kemarahan mereda dengan teknik } \\
\text { "Tiga Napas" atau self-reminder, } \\
\text { tetapi seringkali sulit menerapkan- } \\
\text { nya. }\end{array}$ \\
$\begin{array}{l}\text { Merasa sulit mengendalikan diri saat } \\
\text { marah; Mengekspresikan kemarahan } \\
\text { dengan menangis atau merusak } \\
\text { barang. }\end{array}$ & $\begin{array}{l}\text { Cenderung tidak terlalu reaktif saat } \\
\text { marah dan mengetahui bahwa ia }\end{array}$ & $\begin{array}{l}\text { Lebih mampu berpikir konsekuensi } \\
\text { dapat menghindar dari pemicu marah panjang dari perilaku negatif }\end{array}$ & $\begin{array}{l}\text { saat marah. Namun, masih sulit } \\
\text { menerapkan karena sudah terlalu }\end{array}$ \\
& & $\begin{array}{l}\text { terlebih dahulu untuk menenangkan } \\
\text { diri. Meskipun begitu, terkadang } \\
\text { masih sulit menahan diri apabila }\end{array}$ & $\begin{array}{l}\text { kesal sehingga lupa teknik yang } \\
\text { diajarkan. }\end{array}$
\end{tabular}

MR Melampiaskan kemarahan dengan mengomeli orang lain atau memukul sesuatu karena tidak tahu apa yang harus dilakukan selain hal-hal tersebut.

IN Menampilkan marah dengan berteriak atau menendang meja serta merasa ingin marah terus.

SF Seringkali berpikir negatif akan tindakan yang dilakukan orang lain; Mengekspresikan marah dengan menangis atau merusak barang, bahkan melukai diri.

SS Merasa sulit mengendalikan emosi dan cenderung kasar saat melampiaskan marah kepada siapapun di sekitarnya; Terkadang berusaha melukai diri sendiri saat marah.

NZ Biasanya akan melampiaskan kemarahan pada hal yang membuatnya kesal, misalnya merobek kertas ujian yang nilainya tidak sesuai harapan.

TH Seringkali akan mengambek, menangis, bahkan ingin memukul seseorang untuk melampiaskan kemarahannya.

\section{terpicu marah.}

Lebih mengetahui hal-hal yang dapat dilakukan saat merasa marah.

\author{
Mengetahui beragam teknik untuk \\ meredakan marah, tetapi sejauh ini \\ baru sedikit merasa lega. \\ Lebih memahami tentang emosi dan \\ berusaha berpikir positif.
}

Merasa sudah lebih bisa mengontrol kemarahan dengan menerapkan teknik yang diajarkan, tetapi sering lupa karena kemarahan terlalu intens.

Setelah mendapatkan intervensi, merasa lebih lega karena menerapkan teknik yang diajarkan.

Mengetahui cara mengendalikan marah, tetapi merasa sulit mempraktikkannya di kehidupan sehari-hari.
Lebih mampu mengelola marah walaupun terkadang ada dorongan untuk membalas.

Merasa lebih tenang dan lega saat menggunakan teknik yang diajarkan.

Merasa menjadi lebih sabar, tetapi masih sulit mengendalikan diri ketika sudah sangat marah.

Sudah lebih sering menggunakan teknik dan mampu mengontrol kemarahan.

Merasa lebih mampu mengelola emosi.

Dapat meredakan marah dengan teknik "Tiga Napas", tetapi orang sekitar masih kerap memicu marah. marah terhadap kemarahan pada remaja perempuan (Erickson, 2013; Goldstein et al., 2007).

Tidak adanya perubahan skor tingkat kemarahan partisipan diduga terjadi karena beberapa faktor, salah satunya ialah adanya perbedaan tingkat kerumitan dari masalah pemicu kemarahan yang dialami oleh tiap partisipan. Howells \& Day (2003) menyebutkan bahwa partisipan yang memiliki masalah yang cenderung kompleks kemungkinan akan kurang mendapatkan manfaat dari intervensi manajemen marah dalam bentuk kelompok. Hal tersebut dapat muncul karena isu spesifik yang mereka hadapi kemungkinan tidak tercakup di dalam program intervensi yang diberikan. Pada intervensi ini, terlihat ada beberapa partisipan intervensi yang terlihat memiliki masalah perilaku lebih kompleks dibandingkan partisipan lainnya. Sebagai contoh, terdapat partisipan yang memiliki riwayat melukai diri sendiri sebelum intervensi diberikan, yaitu pada partisipan SF dan SS. Pada individu tersebut, skor kemarahan yang terlihat pada fase post-test tampak tidak mengalami penurunan. Dalam keseharian, beberapa partisipan tersebut juga teramati lebih sering terlibat dalam masalah agresivitas dengan teman lainnya di sekolah dibandingkan partisipan lainnya.

Peneliti menduga bahwa mereka memiliki masalah yang lebih kompleks dan isu yang mereka miliki tidak tercakup di dalam materi intervensi yang diberikan. Oleh sebab itu, kemarahan yang mereka rasakan masih kerap terjadi meskipun mereka sudah mendapatkan pengetahuan tentang cara yang lebih adaptif untuk meredakan kemarahannya. Selain itu, pada beberapa sesi intervensi, beberapa di antara partisipan (SS dan BL) juga teramati menampilkan ekspresi wajah murung dan kesal. Pada momen tersebut, mereka mengatakan sedang menghadapi masalah sejak sebelum sesi intervensi dimulai. Mereka jadi tampak kurang bersemangat dan cenderung tidak antusias dalam mendengarkan materi 
intervensi. Hal tersebut bisa jadi berdampak kepada kondisi mereka yang mungkin kurang mendapatkan manfaat dari intervensi yang diberikan. Guna mengatasi kondisi tersebut, (Hoogsteder et al., 2015) menyebutkan bahwa partisipan dengan masalah yang lebih kompleks dapat diberikan tambahan sesi individual di luar intervensi kelompok yang diberikan. Dengan demikian, manfaat dari intervensi yang diberikan diharapkan bisa menjadi lebih optimal.

Selain tingkat kompleksitas masalah, faktor lain yang diduga berperan terhadap rendahnya dampak dari pemberian intervensi manajemen marah ini adalah kurangnya kesiapan dan motivasi yang dimiliki partisipan dalam mengikuti intervensi. Penelitian menunjukkan bahwa partisipan dengan motivasi yang lebih tinggi dalam mengikuti intervensi manajemen marah cenderung lebih mampu meregulasi kemarahannya (Heseltine et al., 2010). Pada intervensi ini, peneliti menduga bahwa beberapa partisipan kurang termotivasi dalam mengikuti intervensi. Kurangnya motivasi pada partisipan penelitian ini kemungkinan terjadi karena keikutsertaan mereka di dalam sesi intervensi merupakan anjuran yang diberikan oleh pihak sekolah karena remaja tersebut diketahui memiliki masalah terkait kemarahan dan agresivitas. Meskipun partisipan menandatangani informed consent dan bersedia hadir pada seluruh rangkaian intervensi, beberapa di antara partisipan (misalnya $\mathrm{ZH}$ dan BL) mengaku bahwa mereka senang berada di kelas intervensi untuk menghindari kelas pelajaran yang sedang berlangsung. Selanjutnya, masalah motivasi partisipan intervensi terlihat dari kurangnya kesungguhan mereka saat harus mempraktikkan teknik yang diajarkan. Beberapa di antara mereka juga menolak berpartisipasi di dalam kegiatan role-play dan memberikan jawaban. Kurangnya keinginan partisipan dalam mengikuti intervensi kemungkinan berdampak pada rendahnya perubahan yang terjadi pada partisipan setelah intervensi berlangsung.

Selanjutnya, masalah lain yang diduga berperan serta terhadap hasil penelitian adalah kurangnya kemampuan generalisasi intervensi manajemen marah di kehidupan sehari-hari. Generalisasi intervensi manajemen marah di kehidupan sehari-hari merupakan unsur yang diperlukan guna mendukung pengimplementasikan teknik manajemen marah di kehidupan sehari-hari (Goldstein et al., 2007). Pada intervensi ini, hampir seluruh partisipan mengakui bahwa mereka mudah mempelajari dan menggunakan teknik pengelolaan marah yang diajarkan saat sesi berlangsung. Mereka juga lebih banyak menampilkan respon kemarahan yang non-agresif selama sesi intervensi berlangsung. Akan tetapi, partisipan merasa bahwa penerapan teknik tersebut sangat sulit dilakukan ketika menghadapi situasi yang memicu kemarahan di kehidupan sehari-hari. Kesulitan dalam penerapan tersebut tampaknya berdampak pada rendahnya perubahan tingkat kemarahan pada para partisipan meskipun mereka telah mendapatkan intervensi.
Terdapat beberapa hal yang masih perlu ditingkatkan untuk intervensi manajemen marah berikutnya bagi kelompok remaja perempuan, misalnya mempertimbangkan pengelompokan partisipan intervensi dengan masalah kemarahan yang cenderung mirip. Dalam hal ini, partisipan dengan permasalahan kemarahan dan agresivitas lebih kompleks dapat dikelompokkan dengan partisipan dengan karakteristik serupa. Dengan adanya pengelompokan tersebut, materi intervensi yang diberikan juga dapat disesuaikan dengan kebutuhan kelompok. Selain itu, intervensi berikutnya dapat secara spesifik mengukur tingkat motivasi dan kesiapan setiap partisipan untuk mengikuti intervensi. Hal tersebut dapat menjadi acuan bagi peneliti untuk memprediksi seberapa besar dampak yang mungkin terjadi pada partisipan setelah intervensi diberikan.

Sementara itu, untuk mengatasi masalah yang berkaitan dengan kurangnya motivasi partisipan dalam melakukan aktivitas pada sesi intervensi, penelitian berikutnya dapat menerapkan sistem pemberian reward kepada partisipan. Pemberian reward tersebut diharapkan dapat meningkatkan keinginan partisipan untuk berpartisipasi aktif di dalam sesi intervensi. Di samping itu, untuk dapat mengatasi adanya 'motivasi lain' yang mungkin muncul pada partisipan (misalnya mengikuti intervensi hanya untuk menghindari kelas), penelitian berikutnya dapat dilaksanakan pada waktu yang tidak bersamaan dengan jam pembelajaran, misalnya seperti pada jam pulang sekolah atau di akhir pekan. Peneliti juga dapat menambahkan materi tentang pentingnya mengelola kemarahan di dalam kehidupan sehari-hari. Dengan demikian, diharapkan partisipan semakin termotivasi untuk mengikuti intervensi yang diberikan.

Selanjutnya, intervensi manajemen marah yang dilaksanakan bagi remaja perempuan nantinya harus secara lebih spesifik mencakup materi yang lebih banyak mencakup persoalan relasional, mulai dari bentuk-bentuk agresivitas relasional, konsekuensi dari perilaku tersebut, hingga cara memperbaiki relasi yang bermasalah (Goldstein et al., 2007). Pertimbangan tersebut didasarkan pada temuan bahwa masalah yang berkaitan dengan relasi lebih berdampak secara negatif pada perempuan dibandingkan laki-laki (Goldstein et al., 2007). Pada intervensi ini, hampir seluruh partisipan mengeluhkan permasalahan yang berkaitan dengan relasi dengan orang lain, baik dengan teman, guru, maupun keluarga. Akan tetapi, materi intervensi yang diberikan kurang memberikan berbagai contoh terkait permasalahan relasional. Padahal, partisipan tampak mendapatkan insight ketika mendapatkan materi yang secara spesifik mencoba membahas persoalan relasional pada sesi tambahan. Oleh sebab itu, ke depannya, materi intervensi manajemen marah yang berkaitan dengan aspek relasional bagi remaja perempuan perlu mendapatkan porsi yang lebih besar. Dengan diberikannya materi intervensi yang spesifik terkait hubungan relasional, diharapkan remaja perempuan dapat lebih memahami contoh-contoh nyata tentang persoalan kemarahan yang kerap mereka 
temui serta bisa mengaplikasikannya di dalam kehidupan sehari-hari.

Hal lain yang juga perlu dipertimbangkan pada intervensi manajemen marah bagi remaja perempuan ke depannya adalah melakukan modifikasi program intervensi agar generalisasi perilaku tidak hanya terjadi saat sesi berlangsung, tetapi juga dapat diaplikasikan pada kehidupan sehari-hari. Pada intervensi ini, partisipan sebenarnya sudah diajak untuk mengaplikasikan teknik pengelolaan marah di kehidupan sehari-hari dengan memberikan mereka pekerjaan rumah berupa mengisi lembar pemantauan kemarahan. Akan tetapi, partisipan cenderung masih jarang menggunakan teknik yang diajarkan di dalam intervensi saat menghadapi permasalahan terkait kemarahan mereka di lingkungan sebenarnya. Pada intervensi berikutnya, mungkin dapat dilakukan modifikasi agar partisipan dapat mempraktikkan langsung teknik pengelolaan marah di kehidupan sehari-hari dengan pemantauan peneliti. Sebagai contoh, peneliti dapat memantau bagaimana partisipan menerapkan hal-hal yang diajarkan selama intervensi saat berada di kelas atau di lingkungan rumah partisipan.

Selanjutnya, pada penelitian berikutnya, intervensi manajemen marah yang diberikan dapat ditambahkan dengan program psikoedukasi kepada orang-orang di sekitar remaja, misalnya kepada orang tua atau guru. Pada penelitian yang dilakukan Pepler et al. (2010), ditemukan bahwa pendekatan multi-sistemik berupa intervensi manajemen marah bagi remaja perempuan serta orang tuanya secara efektif mampu menurunkan tingkat agresivitas remaja tersebut. Adanya keterlibatan orang di sekitar remaja juga dapat menjadi faktor pendukung bagi remaja untuk menerapkan teknik pengelolaan marah yang sudah mereka pelajari selama intervensi (Feindler \& Engel, 2011). Di samping itu, adanya pemberian program tambahan juga diharapkan dapat membuat orang di sekitar remaja lebih memahami masalah agresivitas dan kemarahan pada remaja serta hal-hal apa saja yang dapat dilakukan oleh orang di sekitar dalam menghadapi masalah tersebut. Dengan adanya pengetahuan serta penanganan yang tepat dari orang di sekitarnya, diharapkan remaja menjadi lebih mampu mengatasi masalah agresivitas dan kemarahan yang mereka miliki.

Pada intervensi ini, meskipun hanya terjadi sedikit penurunan skor rata-rata tingkat kemarahan partisipan, terdapat beberapa hal positif yang terjadi pada partisipan berdasarkan penilaian kualitatif. Setelah mendapatkan intervensi, terlihat bahwa partisipan menjadi lebih paham tentang beragam teknik mengelola marah secara tepat. Hal tersebut terlihat dari jawaban partisipan seputar materi intervensi pada lembar post-test $\neg$ dan follow-up. Temuan tersebut sejalan dengan penelitian Heseltine et al. (2010) yang juga menemukan adanya peningkatan pengetahuan partisipan tentang marah setelah mendapatkan intervensi. Perubahan pada aspek pengetahuan ini merupakan suatu langkah yang baik sebelum nantinya partisipan dapat menerapkan pengetahuan yang mereka miliki dalam bentuk tingkah laku. Dengan adanya penambahan pengetahuan, partisipan dapat mengetahui berbagai alternatif tindakan yang dapat dilakukan saat marah dibandingkan melakukan perilaku yang kurang adaptif seperti tindakan agresif.

Secara kualitatif, partisipan juga merasa mendapatkan manfaat dari pemberian teknik-teknik praktis untuk meredakan kemarahan. Sebagai contoh, beberapa partisipan yang mempraktikkan teknik pengelolaan marah seperti teknik "Tiga Napas" mengatakan bahwa ketika mereka menggunakan teknik tersebut, mereka dapat merasa lebih lega sehingga kemarahan yang mereka rasakan mereda. Selain itu, partisipan juga merasa bahwa mereka mulai mampu mengenali dan mengendalikan kondisi ketika mereka marah, meskipun hal tersebut belum secara signifikan mengubah kondisi mereka saat ini.

Penelitian mengenai efektivitas manajemen marah bagi remaja perempuan merupakan suatu hal yang tergolong baru di Indonesia. Adanya penelitian mengenai efektivitas intervensi manajemen marah bagi remaja perempuan merupakan suatu hal yang baik mengingat intervensi semacam ini biasanya lebih banyak dilakukan pada kelompok remaja laki-laki dibandingkan pada remaja perempuan (Blake \& Hamrin, 2007). Penelitian serupa masih perlu dikembangkan agar peneliti dapat memformulasikan intervensi yang tepat untuk mengatasi masalah agresivitas dan kemarahan pada remaja perempuan di Indonesia. Hasil dari penelitian ini dapat dijadikan sebagai rujukan dan bahan evaluasi untuk melakukan penelitian serupa di masa mendatang. Selain itu, hasil penelitian ini juga dapat digunakan oleh praktisi untuk mempertimbangkan sejumlah aspek sebelum memberikan intervensi terkait masalah agresivitas dan kemarahan pada remaja perempuan. Dalam hal ini, praktisi dapat mempertimbangkan karakteristik remaja perempuan yang memiliki perbedaan dengan remaja lakilaki, termasuk pemberian materi tertentu yang menjadi isu bagi kelompok perempuan. Dengan dikembangkannya program yang spesifik, diharapkan masalah pada remaja perempuan dapat teratasi sebelum berkembang menjadi suatu problem yang serius di masa mendatang.

\section{Simpulan}

Berdasarkan hasil penelitian, terlihat bahwa intervensi manajemen marah menggunakan Teen Anger Management and Education (TAME) memberikan dampak pada penurunan skor rata-rata kemarahan partisipan dari fase pre-test, post-test hingga follow-up. Akan tetapi, penurunan skor ini tidak tergolong signifikan secara statistik sehingga dapat disimpulkan bahwa intervensi yang diberikan belum cukup efektif dalam mengatasi masalah agresivitas dan emosi pada terhadap remaja perempuan. Sementara itu, berdasarkan penilaian kualitatif, terlihat bahwa seluruh remaja perempuan yang menjadi partisipan intervensi merasakan adanya manfaat dari intervensi manajemen marah yang diberikan. Dalam hal ini, mereka mendapatkan pengetahuan tentang sejumlah teknik pengelolaan marah dan terkadang mengaplikasikan 
teknik mengelola marah tersebut dalam kehidupan seharihari. Adanya teknik mengelola marah membuat partisipan mampu melakukan hal-hal yang lebih adaptif untuk meredakan kemarahannya. Hal tersebut cukup bermanfaat mengingat sebelum intervensi diberikan, partisipan cenderung melakukan tindakan agresif saat mengalami kemarahan. Meskipun sudah mengetahui teknik pengelolaan marah, kendala yang dihadapi para partisipan adalah mereka belum sepenuhnya mampu mempraktikkan teknik tersebut saat berada di situasi yang memicu kemarahan.

Penelitian mengenai efektivitas manajemen marah bagi remaja perempuan merupakan suatu hal yang tergolong cukup baru di Indonesia. Penelitian ini memberikan gambaran bahwa intervensi TAME yang diadaptasi dari penelitian Feindler \& Gerber (2008) dapat diaplikasikan di Indonesia. Remaja perempuan tampak mendapatkan manfaat dari intervensi yang diberikan, di antaranya terdapat perubahan dalam aspek kognitif, di mana mereka dapat melihat suatu situasi secara lebih objektif, serta mampu mengaplikasikan strategi mengelola kemarahan yang diajarkan di dalam kehidupan sehari-hari. Akan tetapi, penelitian ini masih terbatas karena belum banyak memberikan contoh kasus yang spesifik terjadi pada remaja perempuan di kehidupan sehari-hari. Meskipun tidak ditemukan hasil yang signifikan secara kuantitatif, hasil dari penelitian ini dapat dijadikan sebagai bahan evaluasi dan rujukan untuk melakukan penelitian lanjutan di masa mendatang. Selain itu, penelitian ini juga dapat bermanfaat bagi praktisi untuk memperhatikan berbagai aspek yang perlu dipertimbangkan saat hendak memberikan program intervensi terkait masalah agresivitas dan kemarahan bagi remaja perempuan. Pada penelitian mendatang, peneliti perlu memperhatikan sejumlah masalah spesifik yang mungkin dimiliki oleh partisipan. Selain itu, materi intervensi yang diberikan dapat ditambahkan dengan isu-isu terkini yang terjadi di lingkungan remaja perempuan. Dengan demikian, diharapkan program yang diberikan diharapkan dapat lebih tepat sasaran dan memberikan manfaat yang lebih besar bagi partisipan.

\section{Referensi}

Baxendale, S., Cross, D., \& Johnston, R. (2012). A review of the evidence on the relationship between gender and adolescents' involvement in violent behavior. Aggression and Violent Behavior, 17(4), 297-310. https://doi.org/10.1016/j. avb.2012.03.002

Berkowitz, L. (2012). A Different View of Anger: The Cognitiveneoassociation conception of the relation of anger to aggression. Aggressive Behavior, 38, 322-333. https://doi. org/10.1002/ab.21432

Blake, C. S., \& Hamrin, V. (2007). Current approaches to the assessment and management of anger and aggression in youth: A review. Journal of Child and Adolescent Psychiatric Nursing, 20(4), 209-221. https://doi.org/10.1111/j.17446171.2007.00102.x
Budi, C. S. (2019, August 16). Fakta baru kasus remaja ditemukan tinggal tulang, berkata kasar hingga tak menyesal. https://regional.kompas.com/read/2019/08/16/ 06104561/fakta-baru-kasus-remaja-ditemukan-tinggaltulang-berkata-kasar-hingga-tak?page=all

Burt, I. (2014). Identifying gender differences in male and female anger among an adolescent population. The Professional Counselor, 4(5), 531-540. https://doi.org/10.15241/ib.4.5. 531

Buss, A. H., \& Perry, M. (1992). The aggression questionnaire. Journal of Personality and Social Psychology, 63(3), 452-459. https://doi.org/10.1037//0022-3514.63.3.452

Candelaria, A. M., Fedewa, A. L., \& Ahn, S. (2012). The effects of anger management on children's social and emotional outcomes: A meta-analysis. School Psychology International, 33(6), 596-614. https://doi.org/10.1177/0143034312454360

Chaplin, T. M., \& Aldao, A. (2013). Gender differences in emotion expression in children: A meta-analytic review. Psychological Bulletin, 139(4), 735-765. https://doi.org/10. 1037/a0030737

Collins, T. P. (2014). Addressing mental health needs in our Schools: Supporting the role of school counselors. The Professional Counselor, 4(5), 413-416. https://doi.org/10. 15241/tpc.4.5.413

Down, R., Willner, P., Watts, L., \& Griffiths, J. (2011). Anger management groups for adolescents: A mixed-methods study of efficacy and treatment preferences. Clinical Child Psychology and Psychiatry, 16(1), 33-52. https://doi.org/10. 1177/1359104509341448

Erickson, J. A. (2013). The efficacy of aggression replacement training with female juvenile offenders in a residential commitment program. In Dissertation Abstracts International Section A: Humanities and Social Sciences. University of South Florida.

Fadhli, H. (2019, April 11). Berawal dari bully di medsos, begini kronologi kasus Audrey. https://news.detik.com/berita/d4506079/berawal-dari-bully-di-medsos-begini-kronologikasus-audrey

Feindler, E. L., \& Engel, E. C. (2011). Assessment and intervention for adolescents with anger and aggression difficulties in school settings. Psychology in the Schools, 48(3), 243-253. https://doi.org/10.1002/pits.20550

Feindler, E. L., \& Gerber, M. (2008). TAME: Teen anger management education. In C. W. LeCroy (Ed.), Handbook of evidence-based treatment manuals for children and adolescents (2nd ed., pp. 139-169). Oxford University Press.

Fives, C. J., Kong, G., Fuller, J. R., \& DiGiuseppe, R. (2011). Anger, aggression, and irrational beliefs in adolescents. Cognitive Therapy and Research, 35(3), 199-208. https:// doi.org/10.1007/s10608-009-9293-3

Gestantya. (2014). Efektivitas intervensi manajemen marah kelompok untuk mengatasi emosi marah pada remaja perilaku kekerasan di lapas anak pria tangerang. Universitas Indonesia. 
Goldstein, N. E. S., Dovidio, A., Kalbeitzer, R., Weil, J., \& Strachan, M. (2007). Anger management for female juvenile offenders: Results of a pilot study. Journal of Forensic Psychology Practice, 7(2), 1-28. https://doi.org/10.1300/ J158v07n02_01

Herts, K. L., McLaughlin, K. A., \& Hatzenbuehler, M. L. (2012). Emotion dysregulation as a mechanism linking stress exposure to adolescent aggressive behavior. Journal of Abnormal Child Psychology, 40, 1111-1122. https://doi.org/ 10.1007/s10802-012-9629-4

Heseltine, K., Howells, K., \& Day, A. (2010). Brief anger interventions with offenders may be ineffective: A replication and extension. Behaviour Research and Therapy, 48(3), 246-250. https://doi.org/10.1016/j.brat.2009.10.005

Hoogsteder, L. M., Stams, G. J. J. M., Figge, M. A., Changoe, K., van Horn, J. E., Hendriks, J., \& Wissink, I. B. (2015). A meta-analysis of the effectiveness of individually oriented Cognitive Behavioral Treatment (CBT) for severe aggressive behavior in adolescents. Journal of Forensic Psychiatry and Psychology, 26(1), 22-37. https://doi.org/10. 1080/14789949.2014.971851

Hornsveld, R. H. J., Zwets, A. J., Leenaars, E. P. E. M., Kraaimaat, F. W., Bout, R., Lagro-Janssen, T. A. L. M., \& Kanters, T. (2018). Violent female offenders compared with violent male offenders on psychological determinants of aggressive behavior. International Journal of Offender Therapy and Comparative Criminology, 62(2), 450-467. https://doi.org/10.1177/0306624X16648109

Howells, K., \& Day, A. (2003). Readiness for anger management: Clinical and theoretical issues. Clinical Psychology Review, 23(2), 319-337. https://doi.org/10.1016/S02727358(02)00228-3

Jahanian, R., \& Alizadeh, M. (2018). The effect of anger management skills training (AMST) on aggressive behaviors among female adolescent students. Psychology and Education: An Interdisciplinary Journal, 55, 85-92.

Kementerian Pemberdayaan Perempuan dan Perlindungan Anak. (2020). Survei nasional pengalaman hidup anak dan remaja (SNPHAR) tahun 2018 - fakta kekerasan terhadap anak di Indonesia. https://www.kemenpppa.go.id/lib/uploads/slider/ 49b98-infografis-snphar-2018.pdf

Kokko, K., Tremblay, R. E., Lacourse, E., Nagin, D. S., \& Vitaro, F. (2006). Trajectories of prosocial behavior and physical aggression in middle childhood: Links to adolescent school dropout and physical violence. Journal of Research on Adolescence, 16(3), 403-428. https://doi.org/10.1111/j. 1532-7795.2006.00500.x

Krahé, B. (2013). The social psychology of aggression. In Hove (Ed.), The Social psychology of aggression, second edition (2nd ed.). Psychology Press. https://doi.org/10.4324/ 9780203082171

Liu, J., Lewis, G., \& Evans, L. (2013). Understanding aggressive behaviour across the lifespan. Journal of Psychiatric and Mental Health Nursing, 20, 156-168. https://doi.org/10. 1111/j.1365-2850.2012.01902.x
Lochman, J. E., Barry, T., Powell, N., \& Young, L. (2010). Anger and aggression. In D. W. Nangle, D. J. Hansen, C. A. Erdley, \& P. J. Norton (Eds.), Practitioner's Guide to Empirically Based Measures of Social Skills (pp. 155-166).

Mokhber, T., Masjedi, A., \& Bakhtiari, M. (2016). The effectiveness of anger management training on decreasing the anger of unsupervised girl adolescents. Open Journal of Medical Psychology, 5(4), 66-72. https://doi.org/https://doi. org/10.4236/ojmp.2016.54008

Nasrizulhaidi, Minauli, I., \& Andria, E. (2015). Efektivitas Anger management training untuk menurunkan agresivitas pada remaja disruptive behavior disorders. Jurnal Psikologi, 11(1), 12-18.

Neumann, A., Van Lier, P. A. C., Frijns, T., Meeus, W., \& Koot, H. M. (2011). Emotional dynamics in the development of early adolescent psychopathology: A one-year longitudinal study. Journal of Abnormal Child Psychology, 39(5), 657-669. https://doi.org/10.1007/s10802-011-9509-3

Oh, J. A., Jung, Y. T., \& Lee, Y. J. (2018). The aim of this study is to analyze risk factors that affect school dropout of multicultural adolescents. International Journal of Pure and Applied Mathematics, 118(19), 935-949.

Pepler, D., Walsh, M., Yuile, A., Levene, K., Jiang, D., Vaughan, A., \& Webber, J. (2010). Bridging the gender gap: Interventions with aggressive girls and their parents. Prevention Science, 11(3), 229-238. https://doi.org/10.1007/ s11121-009-0167-4

Pingault, J. B., Côté, S. M., Lacourse, E., Galéra, C., Vitaro, F., \& Tremblay, R. E. (2013). childhood hyperactivity, physical aggression and criminality: A 19-year prospective population-based study. PLOS ONE, 8(5), 1-7. https://doi. org/10.1371/journal.pone.0062594

Preddy, T. M., \& Fite, P. J. (2012). Differential associations between relational and overt aggression and children's psychosocial adjustment. Journal of Psychopathology and Behavioral Assessment, 34, 182-190. https://doi.org/10. 1007/s10862-011-9274-1

Sukhodolsky, D. G., Smith, S. D., McCauley, S. A., Ibrahim, K., \& Piasecka, J. B. (2016). Behavioral interventions for anger, irritability, and aggression in children and adolescents. Journal of Child and Adolescent Psychopharmacology, 21(6), 58-64. https://doi.org/10.1089/cap.2015.0120

Sullivan, T. N., Garthe, R. C., Goncy, E. A., Carlson, M. M., \& Behrhorst, K. L. (2017). Longitudinal relations between Beliefs Supporting Aggression,Anger Regulation, and Dating Aggression among Early Adolescents. Journal of Youth and Adolescence, 46, 982-994. https://doi.org/10. 1007/s10964-016-0569-0

Willig, C. (2013). Introducing qualitative research in psychology third edition. In Handbook of qualitative research (3rd ed.). Open University Press.

Zamani, L. (2020, August 14). Video merundung temannya viral, 9 remaja putri di Solo diamankan polisi. https://regional. kompas.com/read/2020/08/14/23062211/video-merundungtemannya-viral-9-remaja-putri-di-solo-diamankan-polisi 